\title{
Byzantine Liturgical Hymnography: a Stumbling Stone for the Jewish-Orthodox Christian Dialogue?
}

\author{
Alexandru IONițA $\breve{~}^{*}$
}

This article discusses the role of Byzantine liturgical hymnography within the Jewish-Orthodox Christian dialogue. It seems that problematic anti-Jewish hymns of the Orthodox liturgy were often put forward by the Jewish side, but Orthodox theologians couldn't offer a satisfactory answer, so that the dialogue itself profoundly suffered. The author of this study argues that liturgical hymnography cannot be a stumbling stone for the dialogue. Bringing new witnesses from several Orthodox theologians, the author underlines the need for a change of perspective. Then, beyond the intrinsic plea for the revision of the anti-Jewish texts, this article actually emphasizes the need to rediscover the Jewishness of the Byzantine liturgy and to approach the hymnography as an exegesis or even Midrash on the biblical texts and motives. As such, the anti-Jewish elements of the liturgy can be considered an impulse to a deeper analysis of Byzantine hymnography, which could be very fruitful for the Jewish-Christian Dialogue.

Keywords: Jewish-Orthodox Christian Dialogue; Byzantine Hymnography; anti-Judaism; Orthodox Liturgy.

\section{Introduction}

The dialogue between Christian Orthodox theologians and Jewish representatives is by far one of the least documented and studied inter-religious interchanges. However, in recent years several general approaches to this topic have been issued ${ }^{1}$ and a complex study of it by Pier Giorgio Taneburgo has even been published. ${ }^{2}$ Yet, because not all the reports presented at different Christian-Jewish joint meetings have been published and also,

\footnotetext{
Alexandru Ioniță, research fellow at the Institute for Ecumenical Research, Lucian Blaga University of Sibiu. Address: Str. Mitropoliei 30, Sibiu, Romania, e-mail: alexandru.ionita@ ulbsibiu.ro

1 Shorter overviews worth mentioning here are: Petra Heldt, "A Brief History of Dialogue Between Orthodox Christians and Jews", in: Immanuel 26-27 (1994), p. 211-224; Gary Vachicouras, "Le dialogue de l'Église orthodoxe avec la Tradition juive", in: Contacts 58 (2006), p. 516-527; Alina Pătru, "Der bilaterale Dialog zwischen Orthodoxie und Judentum ab den 70-er Jahren", in: Review of Ecumenical Studies 2 (1/2010), p. 69-81.

2 Pier Giorgio Taneburgo, L'ecumenismo delle radici. Cristiani ortodossi ed ebrei: storia dei rapporti, prospettive di dialogo, Verona, Il Segno dei Gabrielli 2017. Another consistent study was offered by Thomas Kratzert, „Wir sind wie die Juden”. Der griechisch-orthodoxe Beitrag zu einem Ökumenischen jüdisch-christlichen Dialog, Studien zu Kirche und Israel 16, Berlin, Institut Kirche und Judentum 1994.
} 


\section{Alexandru Ioniță}

since one often learns about the content of the discussion through pressreleases that are inherently general and synthetic, there remain multiple difficulties for those who want to study Jewish-Christian Orthodox relations. However, this paper does not aim to portray the history of the dialogue ${ }^{3}$ but rather to unveil the "stumbling stone" or "apple of discord" between Jews and Christian Orthodox and nonetheless to launch a working hypothesis concerning that. The disagreement lies in nothing other than the Orthodox Liturgy, more precisely, the Byzantine hymnography ${ }^{4}$. On repeated occasions both during official sessions of international ecumenical gatherings, but especially during meetings held between Jews and Christian Orthodox academics, various anti-Jewish details of the Byzantine hymnography have been imputed to the Christians as forming a remarkable impediment against deepening Jewish-Christian relations. In the following, I shall undertake an analysis of these statements referring to hymnography as they occur in official discussions and compare it with some Orthodox authors with the intent of contributing to overcoming this turning point in the dialogue.

For reasons easy to guess, ecumenical dialogue is a fragile topic for all Eastern Europe: the Orthodox countries of this area have lived for centuries under Ottoman occupation, and later on, the Communist regimes brought their immense contribution to the isolation of these lands from contact with West European achievements in terms of cultural and religious dialogue. Nowadays, this results in a harsh opposition between very conservative and pro-modern groups in Eastern Europe. At the same time, the West European model for Jewish-Christian dialogue initiated by the Protestant Churches and Roman Catholics has either not been received at all or its acceptance by the Orthodox requires some more time. However, one complication dealing with methodology should be added to the top of the list t: any attempt at revising the liturgical texts is felt by the Orthodox as threatening to Orthodox identity itself. The Christian Orthodox have gone through the centuries solely on the basis of their Liturgy and through partaking in the Church service which (especially during periods of foreign political authorities) was the only medium able to accommodate the public manifestation of their Christian identity. Liturgy, understood now in broad terms as encompassing the whole Byzantine rite, was, at the same time, the tool through which the Christian could access the biblical texts and this, in itself, complicates the

\footnotetext{
3 For a recent approach see the contribution of Éliane Poirot OCD in this issue of the Review of Ecumenical Studies 2, 2019.

4 When I am speaking about Liturgy I mean the whole range of liturgical services held in the Orthodox Church, which always use the Byzantine rite, the only known ritus of the Orthodox Church.
} 
analysis. Beside this, if one includes the intricate millenary history between Christians of the Middle East and Jews, and furthermore adds the new approach of the Orthodox Patriarchate of Jerusalem and its relation with the state of Israel, ${ }^{5}$ the whole picture becomes even more dramatic.

\section{Anti-Jewish Hymnography in the Official Dialogue and Particular Orthodox Theological Views}

One of the first Orthodox voices for the revision of the hymnography is Amilkar Alivizatos. In January 1960, he publicly called the Orthodox Church to "revise ( $\delta \mathrm{t} \omega \rho \theta \omega \sigma \varepsilon \omega \varsigma)$ " the offending hymns regarding Judaism. ${ }^{6}$ Short, but penetrative, the argument of this Greek Orthodox theologian, who asks for the efforts of all the Orthodox liturgists to call for a committee dedicated to this issue, does not fall short of emphasizing the right of the Jewish nation to have an independent state. ${ }^{7}$ However, this position found resonance neither with liturgists nor the officials of the Orthodox Churches. Yet, at a short distance from this, the Orthodox became officially involved in the Ecumenical movement and that had the effect of widely spreading the theme among them. In particular, the Orthodox soon became exposed to the profound changes undertaken by Protestant (starting in 1948) and Catholic circles after Vatican Council II (1965). This encounter with Christian alterity had steadily determined Orthodox awareness of the need to discuss the impact modernity had upon the Liturgy of the Church and upon other problems arising from the meeting of the Orthodox Churches with the realities of the modern world. The climax of this trajectory is the report of the inter-Orthodox consultation on "Renewal in Orthodox Worship" (Bucharest, 1991) ${ }^{8}$. There we find a conclusion about "uncharitable ideas within the Liturgy", where it is stated:

5 Critical voices towards the "western" way of Jewish-Christian Dialogue: Laurent Kloeble, "Note sur Jean Chrysostome et les Juifs", in: Sens 384 (2013), p. 837-842; Mireille Cohen, Sandrine Caneri, "Recontextualiser les Saints Pères et ne pas juger", in: Sens 384 (2013), p. 843-849, but also Michael Azar, "Jewish-Christian Relations and Orthodox Ecumenical Participation", in: Public Orthodoxy. The Orthodox Christian Study Center of Fordham University, https://publicorthodoxy.org/2015/10/22/jewish-christian-relations-and-orthodox-ecumenical-participation/, viewed on March 17, 2019.



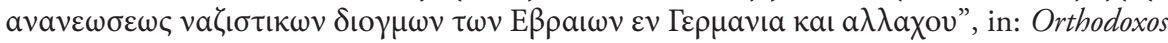
Skepsis 3 (1960), p. 5-8.

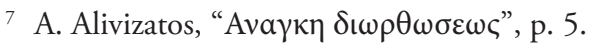

8 Report of an Inter-Orthodox Consultation "Renewal in Orthodox Worship", Bucharest, Romania, 21-27 October 1991, in: Gennadios Limouris (ed.), Orthodox Visions of Ecumenism: Statements, Messages and Reports on the Ecumenical Movement 1902-1992, Geneva, WCC Publications 1994, p. 180-185. 
It is unfortunate that some of the chants in the Good Friday Service of the Orthodox Church contain portions where hatred against the Jews is expressed. They are classified as sinners without any hope of redemption and curses are heaped on them. A close scrutiny is necessary to remove such portions from Orthodox services. ${ }^{9}$

Although it had already been asked many decades ago by the Greek theologian, it seems that the Orthodox Commission for Orthodox Worship only now perceives the importance and need for change. But these words are all we can discern from this commission. Only the need for "close scrutiny" is noted, without having done anything concrete about that.

The other side of the interchanges has to do with the direct official meetings between Jewish and Orthodox representatives. This dialogue actually began some years after Alivizatos' intervention. Its beginning is also due to people open to dialogue in general and to Judaism in particular, due to the context in which they lived. It is about the pioneering work of Bishop Damaskinos Papandreou of Switzerland, who in 1976 spoke to the JewishChristian Fraternity of Switzerland from an Orthodox perspective about a possible Jewish-Christian dialogue. A year later, the first academic meeting between Orthodox and Jewish theologians took place in Lucerne. Altogether there were ten academic meetings, with no regularity thus making it hard to follow up on their publications. It can be noted how the first encounters dealt with very difficult, theological topics, and how, beginning with the fifth meeting, things have changed. ${ }^{10}$ One of the most important reasons for this change is precisely the Byzantine hymnography, with its anti-Jewish elements.

The culmination point is to be found at the Fourth Meeting (1998), where the Orthodox, having been challenged at each previous meeting to give an answer ${ }^{11}$, succeed in formulating a position about the much-invoked anti-Judaism of the Orthodox Liturgy. There we read:

The Christian Orthodoxy reply stated that any interpretation bearing anti-Jewish slant is avoided and that the hymns have not cultivated a polemical attitude against Judaism. However, the response concluded "that [this] is what we can say for now, without this meaning necessarily that it was our final word on the matter. Even though these texts are of a symbolic nature, the matter re-

\footnotetext{
9 "Renewal in Orthodox Worship", p. 183.

10 See the topics of different meetings in the short description by A. Pătru, "Der bilaterale Dialog", p. 74-79.

11 See, for example, the invitation of Gerhart Riegner to „overcome polemic terminology” in: Communique. Third Academic Meeting between Orthodoxy and Judaism. "Continuity and Renewal" Athens, March 21-24, 1993, in: Immanuel 26-27 (1994), p. $185 f$.
} 
mains uppermost in our mind and is of concern to us because it is of concern to you. Time may perhaps provide further prospects. ${ }^{12}$

This fragment deserves more attention because it gives us the stage of the official discussion regarding anti-Jewish elements in Orthodox hymnography. We observe here that the Orthodox try somehow to avoid addressing the subject directly, saying that these problematic elements are in fact not understood and interpreted polemically against Judaism in the Christian churches. Here is the old patristic attitude at work, which interprets these polemical statements in a typological way: the Jew is not historically understood, but spiritually. When the hymnographer speaks of the sins of the Jew and the Jewish rejection of Jesus as Messiah, Orthodox Christians should understand their own sin and their own rejection of Christ: "we see the sins of the Jews as a type of our own sins. Whenever I reflect on those parts of the liturgy, it always brings to mind how I am no better and often worse." ${ }^{13}$ Thus, the texts may remain unchanged, but catechesis and preaching must accompany them with this new typological perspective. ${ }^{14}$ In addition, the Orthodox Commission says that "this is what we can say for now..." and adds that they responded to this issue precisely because of the insistence on the Jewish side ("because it is of concern to you").

This reply has caused a lack of enthusiasm for future encounters where the following meetings show a loss of interest by both sides. The themes become more general and more ethical, political, ecological. The language becomes more official, and the number of participants decreases. ${ }^{15}$ The fifth academic meeting (Thessaloniki, 2003) has "peace and justice" as its subject, where the Ecumenical Patriarch Bartholomew has "denounced religious fanaticism and rejected attempts by any faith to denigrate others", but he didn't mention the well known problem of anti-Jewish hymnography.

A group of Orthodox clergy and laity who met at Jerusalem in 2007 wanted to overcome this insufficiency and some ambiguity registered over

12 "The Encounter of Orthodoxy and Judaism with Modernity". Fourth Academic Meeting between Orthodoxy and Judaism, Ma'aleh HaChamisha, Israel, 13-16 December 1998, here I would like to thank Dr. Alina Pătru for helping me to access this unpublished text.

13 This is a representative voice of the typological approach, coming from the discussion forum issued by the 2007 Statement of Orthodox Priests in Jerusalem: https://www.christianforums.com/threads/orthodox-priests-remove-anti-semitic-liturgy.7379559/, viewed on April 19, 2019.

14 See the Orthodox repudiation of this interpretation on the anti-Jewish liturgical elements by T. Kratzert, „Wir sind wie die Juden”, p. 181-182.

15 "Faithfulness to Our Sources: Our Common Commitment to Peace and Justice". Fifth Academic Meeting Between Judaism And Orthodox Christianity Held In Thessaloniki, May 2729, 2003, https://www.goarch.org/news/organizations/-/asset_publisher/nlQ9SNgI9Vf/ content/fifth-academic-meeting-between-judaism-and-orthodox-christianity-held-in-thessaloniki-may-27-29-2003?inheritRedirect=false, viewed on April 15, 2019. 
several decades by the Orthodox side. They articulated several points related to the relationship of Orthodoxy with Judaism, among which the following deal with the polemical features of the liturgical inheritance:

Our Heritage. In the spirit of this love we must review our own hymnal heritage (in particular, certain hymns of the Passion Week). We should make sure that everything here is in the spirit of the charity that "suffers long, and is kind; charity envies not; charity vaunts not itself, is not puffed up, does not behave itself unseemly, seeks not her own, is not easily provoked, thinks no evil; rejoices not in iniquity, but rejoices in the truth." (1 Cor. $13.4-6)^{16}$

In spite of the ardent desire expressed here by the Orthodox delegation and of the broad echo of this event in the international press ${ }^{17}$, the Orthodox Churches have not taken any steps towards the public recognition of problems in the liturgical texts, nor did they form a liturgical commission to debate this issue. The next official academic meeting between Orthodox Christianity and Judaism (Athens, 2009) had to acknowledge the lack of effort towards a practical implementation of countless previous commitments and requests from the Jewish side. ${ }^{18}$ Participants had the opportunity to express their concerns about „Education, Xenophobia, Terrorism, Radicalism and Extremism", but they avoided the subject of revising liturgical texts.

16 "To Recognize Christ in His People". The final declaration by the Christian Round Table of Eastern Orthodox priests and cultural representatives from Greece, Georgia, Italy, Russia, and Ukraine visiting Jerusalem, April 20-24, 2007, in: Jewish-Christian Relations. Insights and Issues in the ongoing Jewish-Christian Dialogue, http://www.jcrelations.net/To_Recognize_ Christ_in_His_People_Declaration_ by_a_Round_Table_of_Eastern_Ortho.3156.0.html?L=3\&pdf=1, viewed on April 15, 2019.

${ }_{17}$ Etgar Lefkovits, "Priests: Remove Anti-Semitic Liturgy", in: The Jerusalem Post, April 20, 2007, https://www.jpost.com/Jewish-World/Jewish-News/Priests-Remove-anti-Semitic-liturgy, viewed on April 10, 2019 and „Orthodox Priests Combat Anti-Semitism in Church: Call For Removal of Anti-Jewish Passages from Liturgy”, International Christian Embassy Jerusalem, https://ie.icej.org/news/headlines/orthodox-priests-combat-anti-semitism-church, viewed on April 10, 2019.

18 "The World in Crisis: Ethical Challenges and Religious Perspectives". The $7^{\text {th }}$ Academic Consultation between Orthodox Christianity and Judaism (Athens, 2009): "Those gathered at the consultation were leaders charged with taking the vision of these meetings to their respective communities around the world. We recognized that discussions removed from implementation are insufficient, and the measure of the value of our meetings is that we become better informed and motivated to lead our respective communities in recognizing the urgency of the contemporary global challenges." Available on: https://www.archons.org/-/7th-academic-consultation-between-orthodox-christianity-and-judaism-the-world-in-crisis-ethicalchallenges-and-religious-perspectives, viewed on April 10, 2019. 


\section{Jewish and Christian Orthodox Voices against Anti-Jewish Liturgical Hymnography}

A year later, Felicia Waldman offers an appreciative history of the positive elements from the Orthodox Church regarding the Jews during World War II. There are figures of Romanian (not only Orthodox) clergy and theologians who were involved in saving the Jews during the deportations after 1940. But despite the positive tone and the contribution that is really useful for a Jewish-Christian dialogue, the author points out that ,it remains to solve the problem of the deicide charge, which, unlike the Catholic Church, the Orthodox has not yet given up..."19.

Another important moment for Judeo-Christian relations was the $50^{\text {th }}$ anniversary of Vatican Council II (1965), which revolutionized the Catholic Church's view on Judaism and also issued a number of other official documents and debates among Catholic and Protestant circles. In the midst of these events, which took place all over the world, two Jewish reactions are worth mentioning here. The first is a truly revolutionary statement of several Orthodox ${ }^{20}$ rabbis about (Western) Christianity ${ }^{21}$, and the second contains a renewed request to Christian denominations that have not yet revised their texts and teachings on Judaism. It is more than clear that our hymnographic texts are also covered here:

We ordinarily refrain from expressing expectations regarding other faith communities' doctrines. However, certain kinds of doctrines cause real suffering; those Christian doctrines, rituals and teachings that express negative attitudes toward Jews and Judaism do inspire and nurture anti-Semitism. Therefore, to extend the amicable relations and common causes cultivated between Catholics and Jews as a result of Nostra aetate, we call upon all Christian denominations that have not yet done so to follow the example of the Catholic Church and excise anti-Semitism from their liturgy and doctrines, to end the active mission to Jews, and to work towards a better world hand-in-hand with us, the Jewish people. ${ }^{22}$

19 Felicia Waldman, "Aspecte ale relaţiilor iudeo-creştine în timpul celui de-al Doilea Război Mondial şi astăzi din perspectiva evreiască”, in: Review of Ecumenical Studies 2 (1/2010), p. 39-53.

20 The Jewish-Christian Dialogue started with liberal Jews, not with Orthodox ones.

${ }^{21}$ To Do the Will of Our Father in Heaven: Toward a Partnership between Jews and Christians, Orthodox Rabbinic Statement On Christianity, http://cjcuc.org/2015/12/03/orthodox-rabbinic-statement-on-christianity/, viewed on March 12, 2019: "We recognize that since the Second Vatican Council the official teachings of the Catholic Church about Judaism have changed fundamentally and irrevocably..." The text was translated also into Romanian: http://ddic.ecum.ro/documente/, viewed on March 13, 2019.

22 Between Jerusalem and Rome. Reflections on 50 Years of Nostra Aetate (August 2017), http:// cjcuc.org/2017/08/31/between-jerusalem-and-rome/, viewed on April 17, 2019. 
It seems that the Nostra aetate Catholic statement has had a huge success in improving Jewish-Christian relations in the West. Although there are enough Orthodox voices who speak positively about this Catholic declaration ${ }^{23}$ and it is true that Nostra aetate brings to the forefront of Judeo-Christian relations the Pauline vision of Romans 9-11 - much neglected in the Middle Ages $^{24}$ - however, for Orthodox, the topic of liturgical anti-Judaism is very difficult for several reasons. There are meanwhile enough Orthodox voices who advocate revision and correction of these texts. Among the most known are: Andrew Louth ${ }^{25}$, Sergey Hackel ${ }^{26}$, Ioannis Mourtzios ${ }^{27}$, Eugen Pentiuc ${ }^{28}$, Bogdan Bucur ${ }^{29}$ and Alexandru Ioniță ${ }^{30}$. But all these voices are still simply denunciations of the problem, none of them are a detailed analysis. Concerning the hymnography, B. Bucur and M. Azar have demonstrated that the problem is very complex and is related to the way Fathers of the Church have understood how to do biblical exegesis on biblical texts. ${ }^{31}$ Beyond any

23 See the contribution of Grigorios Larentzakis, "Die Erklärung des II. Vatikanums Nostra Aetate über das Verhältnis der Kirche zu den nichtchristlichen Religionen aus orthodoxer Sicht", in: Hans Hermann Henrix (ed.), Nostra aetate. Ein zukunftsweisender Konziltext, Aachen, Einhard 2006, p. 65-72 and also Alexandru Ioniță, "The Increasing Social Relevance of the Catholic Liturgical and Theological Reform Regarding Judaism (Nostra aetate 4): an Orthodox Point of View”, in: Review of Ecumenical Studies 9 (2/2017), p. 258-269 and the talk offered by Metropolitan Kallistos Ware of Diokleia, „Has God Rejected His People? Reflections on The People of Israel", in: In Communion 6, (October 1996), available on: http://www.orthodoxresearchinstitute.org/articles/misc/kallistos_ware_rejected_his_people. html, viewed on April 10, 2019.

24 A. Ioniță, "Die paulinische Israelogie und ihre liturgische Rezeption in der Ostkirche”, in: Irina Vainovski-Mihai (ed.), New Europe College, Yearbook 2013-2014, Bucharest, 2015, p. 151-184 and idem, "Patristic and Eastern Orthodox Interpretations of Romans 9-11: Overview and Perspectives for the Theological Recovery of a Pauline Text", in: Benyik György (ed.), Interpretations of the Letter to the Romans, Szeged, Jate Press 2018, p. 113-123.

25 Andrew Louth, "Patristic Scholarship and Ecumenism”, in: Cristian Bădiliță (ed.), Patristique et Ecuménisme. Thèmes, contextes, personnages, Paris, Beauchesne 2007, p. 7.

${ }_{26}$ Sergey Hackel, "The Relevance of Western Post-Holocaust Theology to the Thought and Practice of the Russian Orthodox Church", in: Sobornost 20 (1998), p. 7-25.

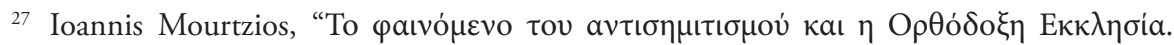

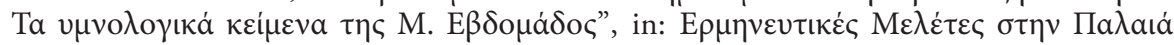

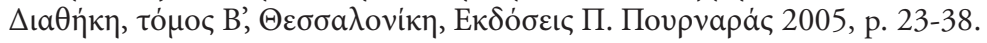

28 Eugen J. Pentiuc, The Old Testament in Eastern Orthodox Tradition, Oxford-New York, Oxford University Press 2014, p. 40f.

${ }_{29}$ Bogdan Bucur, "The Murderers of God, The Lawless Nation of The Jews ...": Coming to Grips with Some of Our Holy Week Hymns, in: Public Orthodoxy, https://publicorthodoxy. org/2018/03/29/bucur-holy-week-2018/, viewed on March 12, 2019.

30 A. Ioniță, "Byzantine Liturgical Texts and Modern Israelogy: Opportunities for Liturgical Renewal in the Orthodox Church", in: Studia Liturgica 44 (1-2/2014), p. 151-162.

31 Bogdan Bucur, "Anti-Jewish Rhetoric in Byzantine Hymnography: Exegetical and Theological Contextualization”, in: St Vladimir's Theological Quarterly 61 (1/2017), p. 39-60; Michael Azar, "Prophetic Matrix and Theological Paradox: Jews and Judaism in the Holy Week 
ecumenical enthusiasm or political correctness, all Orthodox authors are aware that they are just at the beginning of this discussion and that the volume of work is immense, as it is a two-millennia of life together, in which both religious groups fought for identity and supremacy.

\section{Where are we? What can we do?}

So far, we have noticed two important things: first, the dialogue between Orthodox Christians and Jews has not reached the initially desired goal. It has been several decades and anti-Jewish elements in Byzantine hymnography continue to stand in the way of a deeper understanding between the two sister religions. Second, Orthodox theologians were overwhelmed by a difficult task because of the deep attachment to the patristic and liturgical tradition. Beyond the few studies that signal the opening of Orthodox theologians to this theme and the readiness to review some striking anti-Jewish texts, a detailed analysis of the history of the texts, the contexts in which they appeared, and the liturgical language is needed.

Research. Orthodox churches will not be able to cross the mountain of reproach and will not be able to take firm public positions without the help of previously supported scientific effort. An important step in this direction was recently made within the Institute for Ecumenical Research Sibiu ${ }^{32}$. Two important results come to partly fill the gulf felt so far in Judeo-Christian relations from an Orthodox perspective: the first is a website that makes available in Romanian ${ }^{33}$ the most important official documents of the JudeoChristian Dialogue, and the second one is the international conference on „the Byzantine Liturgy and the Jews”, which will debate for the first time in detail the problem of anti-Jewish liturgical texts in Byzantine hymnography, compared to Syrian, Georgian, Armenian and Slavonic liturgical texts.

Of course, it is much easier to start with the negative side, highlighting the anti-Jewish hymns and contextualizing, explaining and eventually rephrasing them. But much more difficult - and this would be the major contribution for a long-term Orthodox perspective - would be the rediscovery of the Jewishness of its own Byzantine tradition. An entirely new and extremely relevant field of research for our perspective is the relationship

and Pascha Observances of the Greek Orthodox Church", in: Studies in Christian-Jewish Relations 10 (1/2015), p. 1-27.

32 See the description of the research project: "Jewish-Christian Dialogue in the Twentieth Century between Religious Tolerance and Anti-Semitism: Documents, Interpretations and Perspectives in the Christian Orthodox Context" (Code: PN-III-P4-ID-PCE-2016-0699), funded by UEFISCDI, on the project-website: www.ddic.ecum.ro, and also in this issue of $R E S$, described by Antoaneta Sabău.

33 See the website at www.ddic.ecum.ro: „Documentele Dialogulului Iudeo-Creștin”. 
between patristic and rabbinical exegesis. In a recent volume on the future of the Jewish-Christian dialogue this topic is described as a research project that gives new impetus to the dialogue ${ }^{34}$. Equally important and necessary for the approach initiated by the research project in Sibiu is the effort to write a history of liturgical books. The beginning made by Stefanos Alexopoulos is commendable ${ }^{35}$, but each liturgical book, in our case the Triodion, needs a separate history.

Educational and Pastoral Approach. Of course, another very demanding field of work, which falls under the responsibility of the church hierarchy, is the ecumenical education of the faithful. Unfortunately, it can be seen how ecumenical dialogue is rather the affair of theology professors and church hierarchs, but not enough efforts were made to disseminate the scientific and diplomatic results. Even more in the case of this delicate topic of liturgical anti-Judaism, clerics and academics should make increased efforts to educate their believers. ${ }^{36}$ What is happening now reflects the very opposite situation: within these groups of believers information sometimes circulates about a global conspiracy planned by the Jews. The last fabrication in this respect is called Super Memorandum, a paper that was eventually signed in 2014 by world leaders along with the religious leaders of the world, among whom were the Ecumenical Patriarch of Constantinople and even abbots of influential monasteries on Mount Athos and in Cyprus. This fictitious document - that nevertheless caused contention and even panic among believers - claims that between 2016 and 2020 a master plan for the reformation of the Orthodox Church must be made. Among other items, we find the following:

34 Agnethe Siquans, "Die Relevanz patristischer (und rabbinischer) Bibelauslegung für den jüdisch-christlichen Dialog heute”, in: Edith Petschnigg et al. (eds.), Hat der jüdisch-christliche Dialog Zukunft? Gegenwärtige Aspekte und zukünftige Perspektiven in Mitteleuropa, Göttingen, Vandenhoeck \& Ruprecht-Vienna University Press 2017, p. 89-94. A very good companion to this approach could be the book of Anna Tzvetkova-Claser, Pentateuchauslegung bei Origenes und den Rabbinen, Early Christianity in the Context of Antiquity Series 7, Frankfurt am Main, Peter Lang 2010.

35 Stefanos Alexopoulos, "Towards a History of Printed Liturgical Books in the Modern Greek State: An Initial Survey”, in: Ecclesia Orans 34 (2017), p. 421-460.

36 One of the book series of the Institute for Ecumenical Research Sibiu is „Documenta Oecumenica”, where official statements of the Church are translated into Romanian for a broader public. After two volumes containing about 1000 pages on the Orthodox Church in the Ecumenical Dialogue (2014), a new volume with documents of the Jewish-Christian Dialogue is forthcoming this year, translated from: Rolf Rendtorff, Hans Hermann Henrix (eds.), Die Kirchen und das Judentum. Band I: Dokumente von 1945-1985, Paderborn, Bonifatius Verlag ${ }^{3} 2001$, and H. H. Henrix, Wolfgang Kraus (eds.), Die Kirchen und das Judentum. Band II: Dokumente von 1986-2000, Paderborn, Bonifatius Verlag 2001. But these sources need time in order to be distributed and received among the Christian faithful. 
Art. 4: From 15.08.2016 no anti-Semitic saint will be feasted. Art. 6: From 16.09.2016 all anti-Semitic hymns will be eliminated from the Church. Art. 7: Starting with 01.07.2016 a feast which will be dedicated to the Jewish Holocaust will be introduced, with a special service in all Christian churches. ${ }^{37}$

In addition to other hard-to-imagine statements of this document, the fact that such writing has created abundant rumours and perplexities in the masses of believers shows that the fear of reform plays a special role here and emphasizes once again the relevance of our theme to the East European milieu.

Fundamentalist circles, especially from Orthodox monasteries, manipulate simple believers, stimulating fear of Christian alterity and Western Europe ${ }^{38}$. The anti-Semitic interwar literature is reprinted without any explanatory introduction and is placed in the hands of young people who attend those monasteries. ${ }^{39}$ On different ultra-orthodox blogs we can find for example intense debates about the "censored" edition of the Enkomia on Good Friday, which in the official Romanian version have left out some anti-Jewish stanzas. Quite a few fundamentalist voices require the complete liturgical texts without any indulgence towards Judaism, pleading for an "uncensored" liturgy ${ }^{40}$. The total lack of openness and interest in this discussion derives precisely from the literature mentioned above, present in some church shops and especially in the Orthodox monasteries.

Another striking example is the current publication of former political prisoners' writings, very appealing to the people, especially young people. In order to better understand what it is about and to perceive the strength of a consistent segment within the Orthodox Church, we must read this fragment:

Jews and Jews alone possess power centres, both in the capitalist, and in the communist world. Although their power is great both in capitalism and in communism, they are not indulged as masters by anybody. This is how Jews got to be the enemies of God, of Christianity, of Islam, of communism and capitalism. By using gold, lie and terror, they humiliate all humankind. One cannot tell

37 The document circulated in its Romanian version via Email and Facebook without any signature, but it reached many people in the Orthodox milieu. It was originally written in Greek.

38 Contrary to this situation see the article by Emma O’Donnell Polyakov, "Christian-Jewish Dialogue in the Monasteries of Jerusalem: An Evolution of Monastic Interreligious Dialogue", in: JEC 53 (4/2018), p. 521-540.

39 See details in: Roland Clark, Holy Legionary Youth: Fascist Activism in Interwar Romania, Ithaca, New York, Cornell University Press 2015.

40 Lumea Ortodoxă: Prohodul Domnului întreg şi neschimbat, https://lumea-ortodoxa.ro/ prohodul-domnului-intreg-si-neschimbat/, viewed on April 10, 2019. 
the truth about them, but with the risk of crucifixion. They kill Christ again.$^{41}[\ldots]$ Their racism is absolute, their materialism is congenital, lie is the centre of their twisted thinking and the more they dwell upon these features, the crueller their disaster will be. Humankind can accept neither the racial terror of Judaism, nor the coarse materialism, nor the mental misinterpretation of Judaism. By divine judgement and will of the people, they have been doomed. You are destroyed, Israel! ${ }^{42}$

The interwar theories of the role of the Jews in the world conspiracy are therefore present and alive in the Orthodox circles that deal with such literature. From here we can better understand the difficulties faced by the Orthodox Churches.

\section{Rediscovering the Jewishness of the Byzantine Hymnography}

After decades of debate over Byzantine liturgical hymnography, we see that the anti-Jewish elements are somehow in the midst of the Orthodox's inability to make any change in their worship. On the other hand, within the bosom of the Orthodox Church there is a massive resistance to any change, but especially to that which concerns anti-Jewish elements. A resentment present for many centuries added to the political experiences of the $20^{\text {th }}$ century makes the situation very complicated. In this context, there is a latent danger that can come into effect in some areas. Those who do not actually know the hymnography and the Byzantine liturgy well are in danger of believing that all Orthodox liturgy or hymnography is anti-Jewish. Generalizations are the most common "sins", and the case of John Chrysostom is famous for this. Just as some Protestant Christians know nothing more about John Chrysostom than that he was an anti-Semitic patristic author, so some Western Christians do not know anything about Orthodox Hymns but that they have anti-Jewish elements ${ }^{43}$.

If we detach ourselves from the passionate debates around anti-Jewish liturgical elements in the East, any interested Christian should actually have access to a quantitative study that still does not exist ${ }^{44}$. Namely, a clear, statistical radiography of the hymns of the whole liturgical year should high-

41 Ioan Ianolide, Deținututul profet, București, Editura Bonifatius 2009, p. 108-9.

42 Ibidem, p. 48.

43 Here I have to thank some fellows from the Collegium Oecumenicum in Munich, with whom I had the opportunity to speak during my research stage between 2008 and 2012. I could observe this attitude also teaching to the non-Orthodox students of the „Ökumene-Semester Hermannstadt" between 2015 and 2018.

44 See the contribution of A. Ioniță, „Mapping the Anti-Jewish Topoi of the Triodion”, at the conference on „Byzantine Liturgy and the Jews”, Sibiu 9-11 July 2019, forthcoming. 
light the fact that anti-Jewish elements are actually a very small percentage compared to the corpus of hymns present in Orthodox churches. In addition, music plays a very important role and this aspect has not yet been approached: it matters a lot if some hymns are sung or just read. Moreover, many of the hymns never reach the ears of an ordinary Orthodox Christian because they are only part of the monastic order..$^{45}$ In this respect, it should be investigated which hymns are put in a musical setting, and so, therefore, are implicitly more influential. The church building with its architecture, the special liturgical moment, the surrounding frescos and the musical support of a particular hymn are actually the media through which a particular text and its message are performed and reach their audience. Therefore, the Jews often mentioned the Good Friday services in their reproaches to the Orthodox. This is understandable because these texts are sung with a very appealing melody, and the participation of the faithful is very high, while other services containing similar statements remain practically "not activated" because they are either not used in worship or they are used only in monasteries. ${ }^{46}$

If only a small part of the hymn is anti-Jewish, then what about the large amount of hymnography that remains free of anti-Jewish animus? This is actually at issue and one of the most valuable research tasks, because Byzantine hymnography and Orthodox liturgy generally contain a profound Semitism, some Orthodox theologians say. Olivier Clément has stressed this feature of the Orthodox tradition many times. He is of the opinion that the Byzantine liturgy is in fact written by "linguistically stylized Semites" 47 and that Orthodox tradition is closer to the Jewish one than to occidental Christianity. Hymnography is positive about the Law especially when celebrating the feasts of the Prophets, or the Maccabees brothers. But also other more deep exegetical and hermeneutical elements that are relevant to the interpretation of biblical texts can be highlighted. New studies on Byzantine hymnography could better outline this, as Sandine Caneri has already showed in an exemplary way, demonstrating that hymnography, like iconography, is

45 For example the service of Compline, read only by monks. In his liturgical canons of Compline, St. Andrew from Crete has some very harsh statements against the Jews. Note that there is no official distinction between the monastic and the parish liturgical rule in Orthodoxy.

46 See: A. Ioniță, "Chanting the Jews in Romanian Byzantine Chant Books: Socio-Political Conditioning during the 19th and 20th Century", at the $8^{\text {th }}$ International Musicological Conference: "Musical and Cultural Osmosis in the Balkans", Bucharest, 2-6 September 2019, forthcoming.

47 Olivier Clément, Patriarhul Eucmenic Bartolomeu I, Adevăr și libertate. Ortodoxia în contemaporaneitate. Convorbiri cu Patriarhul Ecumenic Bartolomeu I, Sibiu, Deisis 1997, p. 168-169. 


\section{Alexandru Ioniță}

nothing more than a midrash to the biblical text ${ }^{48}$. In the same sense, Mère Éliane Poirot began an inventory of positive Byzantine hymns on Temple, the Law, and other Jewish subjects ${ }^{49}$.

It should also be added here that the hymnography actually does not represent the core of the Orthodox Liturgy. Anti-Jewish elements are found in the poetic texts accompanying biblical readings, but the text of the Holy Sunday Mass, the texts of the liturgical Anaphora that comes from St. John Chrysostom and St. Basil the Great not only do not contain such elements, but they are also very biblical and emphasize rather the continuity between Israel and the Church, not a theology of substitution.

\section{Conclusions and Perspective}

During this study we were able to follow how the Jewish-Orthodox Christian Dialogue suffered and still is impeded by the anti-Jewish content of Byzantine hymnography. The first four dialogue sessions addressed theological themes and the discussions were heated, but after the repeated request to respond to the revision of the blatant anti-Jewish texts, the Orthodox theologians could only react with inconsistency. Thus, Byzantine hymnography, with its anti-Jewish elements, has become a sort of "stumbling stone" for this dialogue.

After the fourth session the number of participants decreases and the subjects become very general and less theological. As Th. Kratzert said, studying several Greek authors in the 1990s, we can also say about the entire official dialogue, that Orthodox theologians have tended to explain and justify the existence of anti-Jewish hymns rather than to address them frontally and try to modify or exclude them. The truth is that the Alivizatos prophetic voice of 1960 has not been fulfilled today. On the contrary, today we are witnessing a tension perhaps unimaginable half a century ago, between the fundamentalist and the progressive voices in the same Orthodoxy. His proposal to form a Pan-Orthodox liturgical commission to address this issue was not considered for various reasons. In addition, the Orthodox participants in the dialogue were open, ecumenical, sometimes biblical theologians, but the liturgists were almost absent.

Besides the inherent difficulty of Orthodoxy in criticizing its own tradition and especially the texts of the liturgy, we have been able to see how

\footnotetext{
48 S. Caneri, “Ouvertures Liturgiques”, in: idem, Rencontre de Rébecca au puis. Exégèses rabbinique et patristique de Gn 24, 10-21, Bible dans ses traditions, Paris, Les Editions du Cerf 2014, p. 145-162 and other publications.

49 À la louange de sa gloire. Modification de certains textes de l'office byzantin au regard du mystère d'Israël et de l'Eglise, Mss., 2008, forthcoming in the Studia Oecumenica series of the Ecumenical Institute in Sibiu.
} 
difficult it is in the East European context, because of the literature circulated through church shops and monasteries. This kind of text often has more influence among the people than the official decisions of the ecumenical dialogue, which the church hierarchy did not make enough efforts to disseminate and explain to believers. But despite these difficulties, there are now some prominent voices of some Orthodox theologians who are open and willing to work on reviewing the texts. However, this is still not the case with the official Orthodox Churches.

This study proposes a thorough study of the intimate relationship between the Bible and the Liturgy present in Byzantine hymnography. Realising the fact that anti-Jewish elements constitute only a small part of the hymnographic corpus and that those problematic places may not even be fully heard by Christians are new research tracks that deserve a great deal of effort. It can even be said that Byzantine hymnography is not a stumbling stone to the Jewish-Christian dialogue, but rather a rich mine from which to extract a new way of dialogue. Without a few problematic hymns, the Orthodox liturgy would lose nothing of its theological depth and richness. ${ }^{50}$ On the contrary, the capacity to scientifically and critically address the liturgical texts would develop a necessary process of liturgical renewal in order to recover the essence of our liturgical tradition. A profound analysis of the Orthodox liturgical texts could help us free ourselves from ritual formalism and would help us to discover the meaning of our liturgical heritage that has inherited from Judaism not only the biblical texts, but also many other Jewish elements latently present in our liturgical and spiritual tradition.

50 Ibidem, p. 185. 